ISSN : 2252-3839 (Print)

ISSN : 2549-2403 (On Line)

DOI : 10.28989/compiler.v8i2.514

http://ejournals.stta.ac.id/index.php/compiler/

\title{
PERFORMANCE ANALYSIS OF ILLUMINATION INVARIANT CHANGE DETECTION METHOD FOR DETECTING IMAGE CHANGE IN NIGHT VISION CAMERA
}

Adri Priadana

Program Studi Teknik Informatika

Fakultas Teknik dan Teknologi Informasi

Universitas Jenderal Achmad Yani Yogyakarta

J1. Siliwangi, Ringroad Barat, Banyuraden, Gamping, Sleman

Daerah Istimewa Yogyakarta

Email : adripriadana3202@gmail.com

\begin{abstract}
At present, the use of video cameras is not only limited to documenting events but is also used for surveillance systems. Changes in lighting that occur in the surveillance area is one of the problems that result in a false alarm on the surveillance system. Illumination Invariant Change Detection is a method for detecting image changes on images. This study aims to determine the performance of the Illumination Invariant Change Detection method to detect image changes in night vision surveillance cameras. The Illumination Invariant Change Detection method does not work well for detecting image changes on a night vision camera under dark lighting conditions at an average value of Lux 0 with an infrared lamp on. The accuracy of the application of the method to detect image changes on night vision cameras is $80 \%$ with the selection of the threshold value of the detection of image changes that is 75000 pixels.

Keywords: image change detection, Illumination Invariant, Illumination Invariant Change Detection, night vision camera
\end{abstract}

\section{Latar Belakang Masalah}

Saat ini penggunaan kamera video tidak hanya terbatas untuk mendokumentasikan suatu peristiwa, akan tetapi juga digunakan untuk sistem pengawasan. Hal ini dibuktikan dengan munculnya produk-produk kamera yang mendukung sistem pengawasan. Teknologi kamera pengawas saat ini juga telah dilengkapi dengan LED lighting yang berfungsi membantu pengawasan pada daerah yang kurang cahaya atau gelap (night vision).

Perubahan pencahayaan menjadi salah satu kendala dalam berbagai deteksi dan identifikasi pada sistem pengawasan yang memanfaatkan kamera video seperti pada sistem deteksi wajah [1][2], sistem deteksi objek bergerak [3][4][5][6][7], dan sistem identifikasi objek [8][9]. Perubahan pencahayaan yang terjadi pada area pengawasan menjadi salah satu masalah yang mengakibatkan adanya false alarm pada sistem pengawasan. Ketika sistem pengawasan mendeteksi adanya objek dimana pada kenyataannya objek tersebut hanyalah berasal dari perubahan pencahayaan yang ekstrim, tentunya akan menimbulkan sistem pengawasan menjadi tidak akurat.

Metode Illumination Invariant Change Detection merupakan salah satu metode untuk mendeteksi perubahan citra dimana dilakukan perbandingan antara citra awal atau citra sebelum ada gerakan dengan citra setelah ada gerakan. Metode ini telah banyak diterapkan pada beberapa penelitian seperti pada bidang remote sensing [10][11] dan pada teknologi kendaraan [12]. Metode ini dapat mendeteksi perubahan citra hampir tidak terpengaruh oleh perubahan pencahayaan [13]. Penelitian tersebut menerapkan metode 
Illumination Invariant Change Detection pada kamera Closed Circuit Television (CCTV) sebagai dasar untuk mendeteksi perubahan citra yang di duga sebagai aksi corat-coret dinding dan memberikan sebuah peringatan sedini mungkin. Evaluasi sistem dalam mendeteksi perubahan citra dengan metode tersebut memiliki akurasi 92.86\%. Akan tetapi, pada penelitian tersebut tidak dijabarkan citra referensi yang dijadikan pembanding diambil pada waktu siang atau malam hari. Selain itu, penelitian tersebut baru menerapakan metode Illumination Invariant Change Detection pada satu jenis kamera pengawasan saja, yaitu kamera CCTV. Metode tersebut belum terbukti dapat memiliki akurasi yang baik untuk mendeteksi perubahan citra pada semua jenis kamera pengawasan khususnya kamera night vision. Penelitian ini bertujuan untuk mengetahui kinerja metode Illumination Invariant Change Detection untuk mendeteksi perubahan citra pada tipe kamera pengawasan night vision. Manfaat dari penelitan ini adalah memberikan pengetahuan mengenai seberapa tinggi akurasi yang dihasilkan dari metode Illumination Invariant Change Detection dalam mendeteksi perubahan citra pada tipe kamera pengawasan night vision.

\section{Metodologi Penelitian}

Metode penelitian yang digunakan pada penelitian ini adalah metode penelitian tindakan diamana merupakan studi berupa analisis, pengamatan dan pencatatan penerapan metode Illumination Invariant Change Detection pada kamera night vision, yang tujuannya untuk menghitung akurasi sistem. Tahapan penelitian yang dilakukan dalam penelitian ini terdiri atas tiga tahap yaitu pengumpulan data, perancangan sistem, dan pengujian sistem untuk mengetahui akurasi sistem.

\subsection{Pengumpulan Data}

Pada penelitian data bukan dibuat peneliti tetapi dikumpulkan yaitu berupa citra yang diambil dengan kamera night vision. Citra yang dikumpulkan adalah sebuah citra referensi dan beberapa citra pada periode beberapa periode waktu yang telah ditentukan. Adapun data citra yang digunakan pada penelitian ini ditunjukkan pada tabel 1.

Tabel 1 Data citra

\begin{tabular}{|c|l|c|c|c|}
\hline No & Nama Citra & Waktu Akuisis & Nilai AVG Lux & Infrared \\
\hline 1. & Out_Ref.jpg & 17.00 & 2080 & not active \\
\hline 2. & Out_1.jpg & 17.37 & 336 & not active \\
\hline 3. & Out_2.jpg & 17.44 & 73 & not active \\
\hline 4. & Out_3.jpg & 18.00 & 2 & active \\
\hline 5. & In_Ref.jpg & 10.40 & 28 & not active \\
\hline 6. & In_1.jpg & 10.42 & 4 & not active \\
\hline 7. & In_2.jpg & 10.44 & 0 & active \\
\hline 8. & Out_1_Objek.jpg & 17.37 & 336 & not active \\
\hline 9. & Out_2_Objek.jpg & 17.44 & 73 & not active \\
\hline 10. & Out_3_Objek.jpg & 18.00 & 2 & active \\
\hline 11. & In_1_Objek.jpg & 10.42 & 4 & not active \\
\hline 12. & In_2_Objek.jpg & 10.44 & 0 & active \\
\hline
\end{tabular}

\subsection{Perancangan Sistem}

Proses deteksi perubahan citra pada kamera night vision yang dilakukan pada penelitian ini menerapkan metode Illumination Invariant Change Detection. Secara 
umum urutan proses dari sistem deteksi perubahan citra pada kamera night vision yang dibangun dapat dilihat pada Gambar 1.

Proses deteksi deteksi perubahan citra pada video pada kamera night vision dengan Illumination Invariant Change Detection dilakukan dengan langkah-langkah sebagai berikut.

a. Terdapat tiga masukan dimaan dua diantaranya berupa citra yaitu citra uji dan citra referensi. Masukan yang ketiga berupa nilai threshold dimana pada sistem ini digunakan sebagai dasar untuk menentukan ada tidaknya perubahan citra.

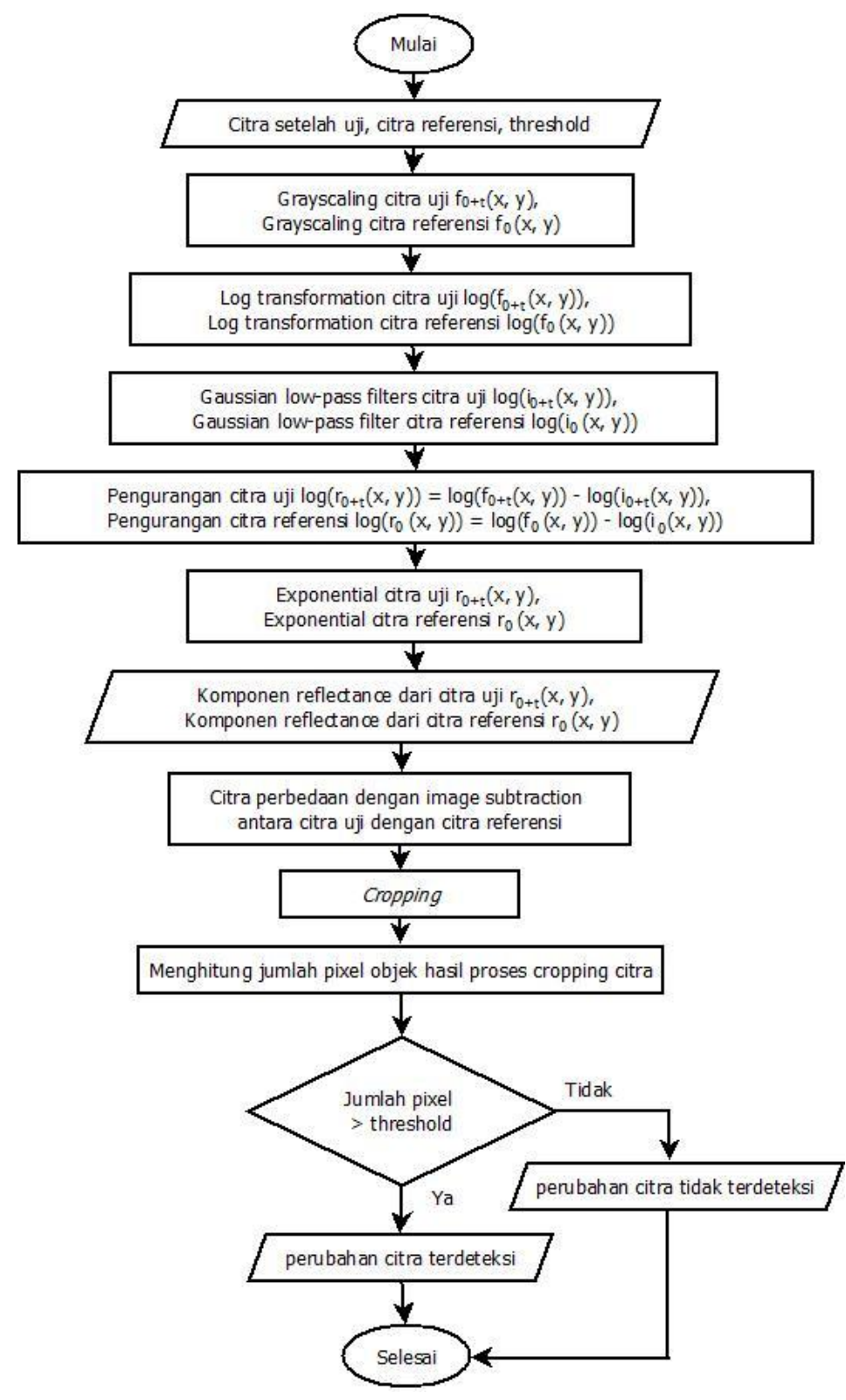

Gambar 1 Desain Sistem

b. Grayscale, tahap ini berfungsi untuk mengkonversi kedua citra masukan dari model warna RGB ke dalam model warna grayscale dimana dilakukan dengan menggunakan persamaan (1) [14]. 


$$
Y=0.299 R+0.587 G+0.1114 B
$$

c. Log transformation, tahap ini berfungsi untuk mengubah hubungan perkalian antara komponen pemantulannya terhadap obyek atau reflectance dengan komponen pencahayaan atau illumination. Bentuk umum dari log transformasi didefinisikan pada persamaan (2) dengan c adalah konstanta dan diasumsikan bahwa $r \geq 0$ [15].

$$
s=c \log (1+r)
$$

d. Low-pass filters dengan Gaussian low-pass filters, tahap ini berfungsi untuk pengaburan citra dimana citra yang kabur merupakan representasi dari citra yang mewakili komponen pencahayaan atau illumination.

e. Pengurangan nilai pixels citra, tahap ini berfungsi untuk mengekstrak komponen reflectance dari kedua citra masukan.

f. Exponential, tahap ini berfungsi untuk menginverse fungsi log transformation pada kedua citra masukan. Bentuk umum dari exponential didefinisikan pada persamaan (3) [15].

$$
s=e^{r / c}-1
$$

g. Image subtraction, tahap ini berfungsi untuk mendapatkan citra perbedaan antara kedua citra masukan dimana keduanya merupakan citra referensi dan citra uji dari hasil proses exponential dimana nilainya adalah absolut.

h. Cropping, tahap ini berfungsi mengekstrak region of interest atau wilayah pengamatan dari citra hasil proses image subtraction.

i. Tahap terakhir pada sistem ini adalah perhitungan jumlah pixel objek atau nilai perbedaan. Nilai perbedaan ini digunakan sebagai dasar untuk menyimpulkan hasil deteksi perubahan citra dimana dilakukan dengan cara membandingkannya dengan nilai threshold yang telah ditentukan. Jika nilai perbedaan lebih besar dari threshold maka dapat disimpulkan bahwa terdeteksi adanya perubahan citra. Sebaliknya, jika nilai perbedaan lebih kecil dari threshold maka dapat disimpulkan bahwa terdeteksi tidak adanya perubahan citra.

\subsection{Pengujian Sistem}

Pengujian sistem diawali dengan memasukan citra referensi dan citra uji. Pengujian sistem pada penelitian ini dilakukan dengan menghitung precision dan recall dimana perhitungan ini pada umumnya digunakan untuk melakukan perhitungan akurasi dari sistem. Precision adalah kemampuan dari sistem untuk tidak mendeteksi kondisi yang tidak benar. Sedangkan recall adalah kemampuan sistem untuk mendeteksi kondisi yang benar. Perhitungan precision dan recall sistem dilakukan dengan menggunakan persamaan (4) dan persamaan (5) [16].

$$
\begin{aligned}
& \text { precision }=\frac{T P}{T P+F P} \times 100 \% \\
& \text { recall }=\frac{T P}{T P+F N} \times 100 \%
\end{aligned}
$$


Untuk mengukur The Percentage Correct Classification (PCC) of system, atau dapat disebut akurasi sistem pada pengukuran deteksi perubahan citra dimana dilakukan dengan menggunakan persamaan (6) [16].

$$
\text { akurasi }=\frac{T P+T N}{T P+T N+F P+F N} \times 100 \%
$$

dimana false positive (FP) menunjukkan adanya perubahan citra yang terdeteksi akan tetapi tidak ada berdasarkan kenyataan. True positive (TP) menunjukkan adanya perubahan citra yang terdeteksi dimana perubahan citra ini memang ada berdasarkan kenyataan. True negative (TN) menunjukkan adanya perubahan citra yang tidak terdeteksi dimana perubahan citra ini memang tidak ada berdasarkan kenyataan. False negative (FN) menunjukkan adanya perubahan citra yang tidak terdeteksi akan tetapi ada berdasarkan kenyataannya.

\section{Hasil dan Pembahasan}

Proses deteksi perubahan citra pada kamera night vision yang dilakukan pada penelitian ini menerapkan metode Illumination Invariant Change Detection. Tahap pertama pada metode ini yaitu mengkonversi kedua citra masukan dari model warna RGB ke dalam model warna grayscale. Adapun citra hasil konversi ditunjukkan pada gambar 2 . Tahap kedua adalah proses Log transformation. Adapun citra hasil log transformation ditunjukkan pada gambar 3. Tahap ketiga adalah proses Low-pass filters dengan Gaussian low-pass filters. Adapun citra hasil dari proses Low-pass filters dengan Gaussian low-pass filters ditunjukkan pada gambar 4. Tahap keempat adalah proses pengurangan nilai pixels citra. Citra hasil dari proses pengurangan nilai pixels citra ditunjukkan pada gambar 5. Tahap ke lima adalah proses Exponential. Citra hasil proses exponential ditunjukkan pada gambar 6. Tahap keenam adalah proses image subtraction. Hasil dari proses ini ditunjukkan pada gambar 7. Tahap ketuju adalah proses cropping. Adapun citra hasil dari porses cropping ditunjukkan pada gambar 8.

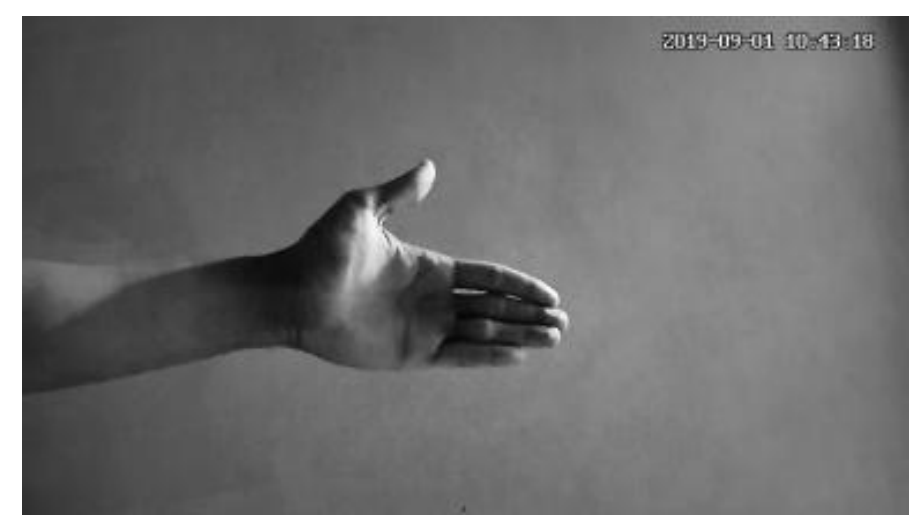

Gambar 2 Citra hasil konversi ke grayscale 


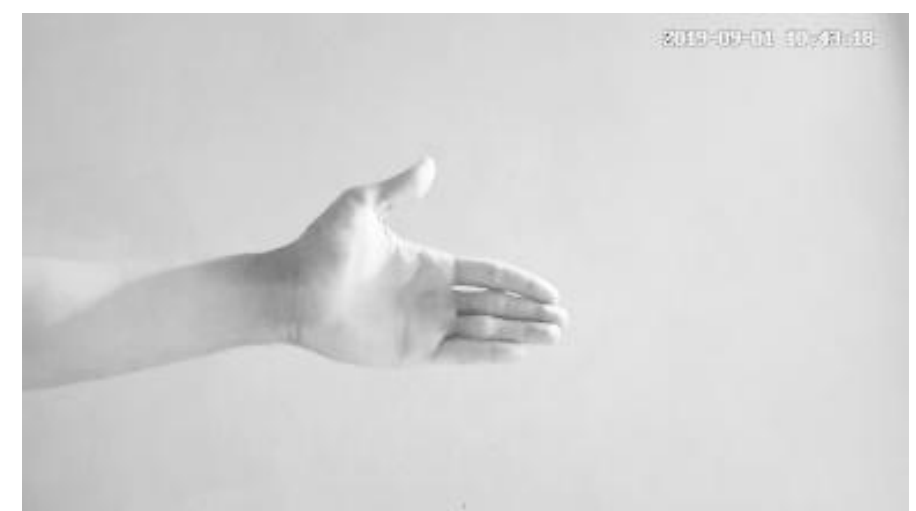

Gambar 3 Citra hasil proses log transformation

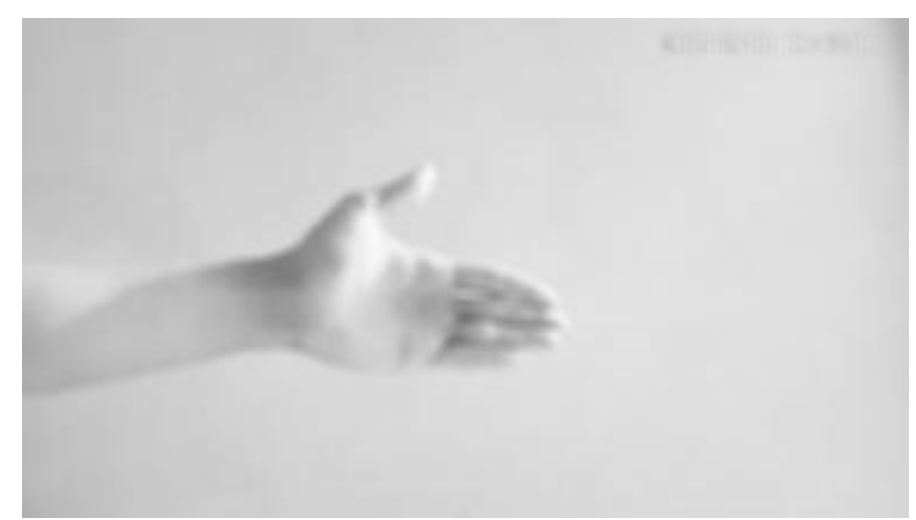

Gambar 4 Citra hasil proses Low-pass filters dengan Gaussian low-pass filters

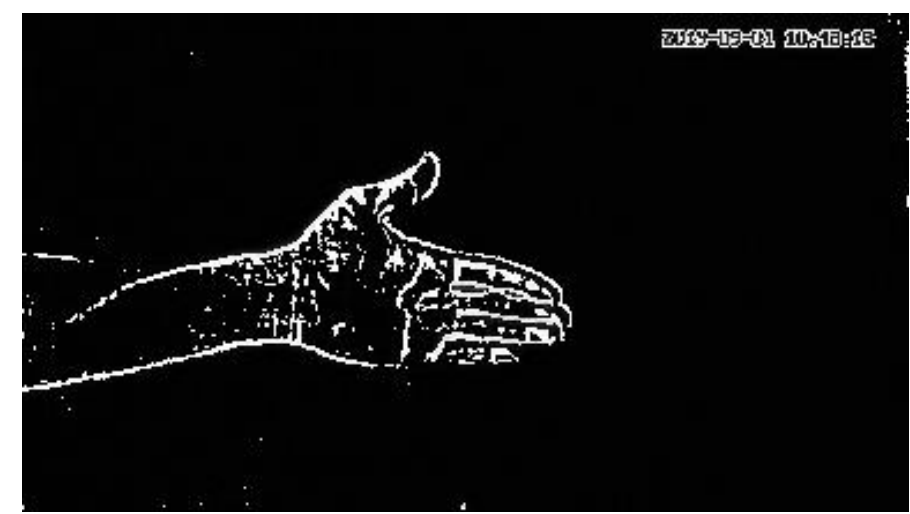

Gambar 5 Citra hasil proses pengurangan nilai pixels citra

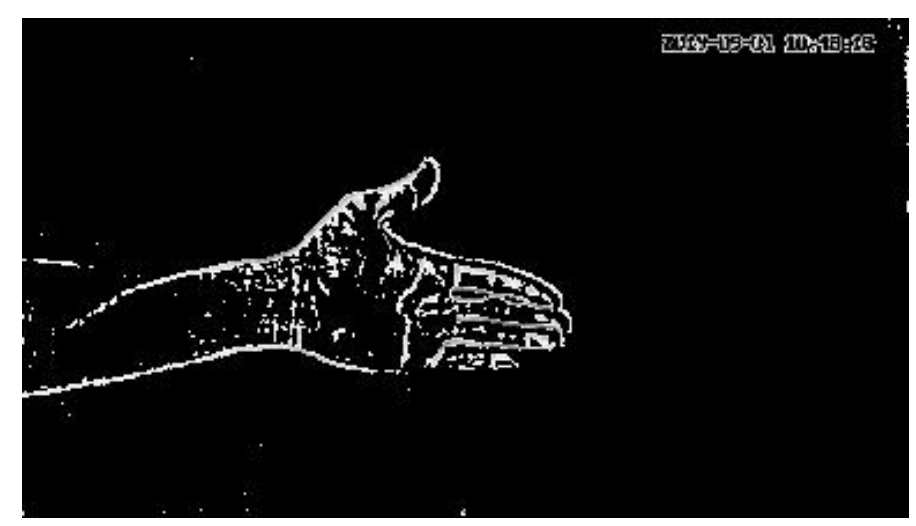

Gambar 6 Citra hasil proses Exponential 


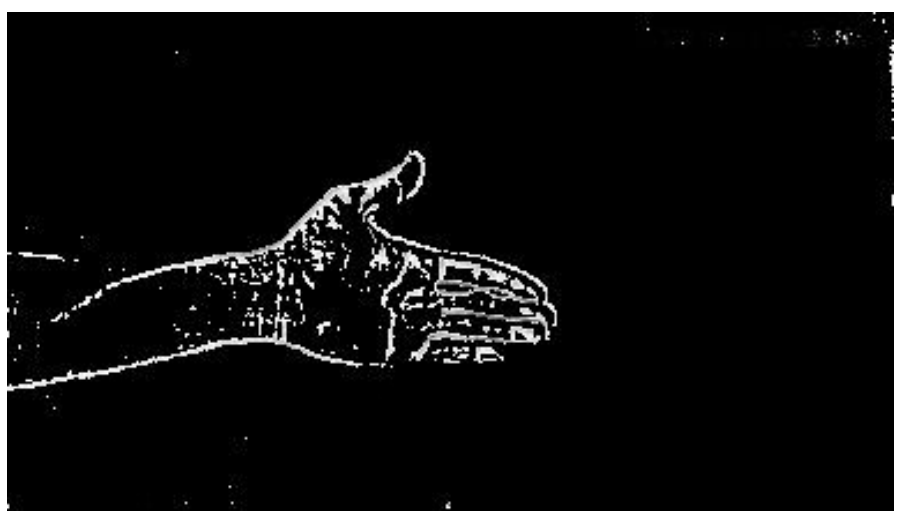

Gambar 7 Citra hasil proses image subtraction

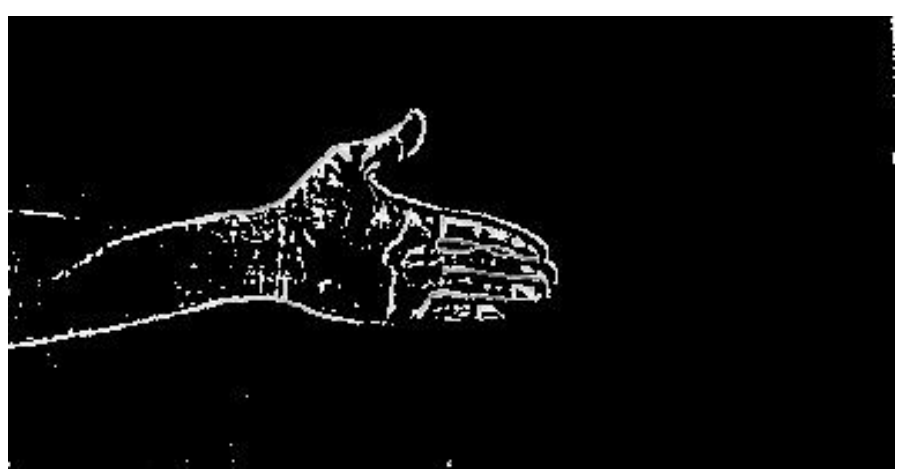

Gambar 8 Citra hasil proses cropping

Tahap terakhir dari metode ini adalah perhitungan jumlah pixel objek atau nilai perbedaan. Nilai perbedaan ini digunakan sebagai dasar untuk menyimpulkan hasil deteksi perubahan citra dimana dilakukan dengan cara membandingkannya dengan nilai threshold yang telah ditentukan. Jika nilai perbedaan lebih besar dari threshold maka dapat disimpulkan bahwa terdeteksi adanya perubahan citra. Sebaliknya, jika nilai perbedaan lebih kecil dari threshold maka dapat disimpulkan bahwa terdeteksi tidak adanya perubahan citra.

Untuk mengetahui kinerja metode Illumination Invariant Change Detection dalam mendeteksi perubahan citra pada kamera night vision adalah dengan cara melihat informasi hasil deteksi perubahan citra yang ditampilkan oleh sistem. Informasi hasil deteksi ditampilkan berdasarkan besarnya nilai perbedaan antara citra referensi dengan citra uji yang kemudian dibandingkan dengan nilai threshold. Untuk menentukan nilai threshold terbaik dilakukan dengan percobaan dengan memilih beberapa nilai threshold dan membandingkan hasilnya. Nilai threshold yang telah diuji adalah nilai threshold yang telah dibandingkan dengan besarnya nilai perbedaan antara citra referensi dengan citra uji untuk semua data citra uji. Hasil percobaan untuk menentukan nilai threshold yang digunakan terdapat pada Tabel 2.

Tabel 2 Hasil percobaan dengan threshold yang berbeda pada deteksi perubahan citra

\begin{tabular}{|c|c|c|l|}
\hline A & B & C & \multicolumn{1}{c|}{ D } \\
\hline 5000000 & $\begin{array}{l}\text { Tidak } \\
\text { Sesuai }\end{array}$ & Sesuai & $\begin{array}{l}\text { Sistem tidak mendeteksi adanya perubahan pada } \\
\text { semua citra uji baik yang sebenarnya tidak ada } \\
\text { perubahan maupun yang sebenarnya ada perubahan }\end{array}$ \\
\hline 1000000 & $\begin{array}{l}\text { Tidak } \\
\text { Sesuai }\end{array}$ & Sesuai & $\begin{array}{l}\text { Sistem tidak mendeteksi adanya perubahan pada } \\
\text { semua citra uji baik yang sebenarnya tidak ada }\end{array}$ \\
\hline
\end{tabular}




\begin{tabular}{|l|l|l|l|}
\hline & & & perubahan maupun yang sebenarnya ada perubahan \\
\hline 100000 & Sesuai & Sesuai & $\begin{array}{l}\text { Sistem mendeteksi adanya perubahan pada hampir } \\
\text { semua citra uji baik yang sebenarnya ada } \\
\text { perubahan maupun yang sebenarnya tidak ada } \\
\text { perubahan }\end{array}$ \\
\hline 50000 & Sesuai & Sesuai & $\begin{array}{l}\text { Sistem mendeteksi adanya perubahan pada hampir } \\
\text { semua citra uji baik yang sebenarnya ada } \\
\text { perubahan maupun yang sebenarnya tidak ada } \\
\text { perubahan }\end{array}$ \\
\hline 10000 & Sesuai & $\begin{array}{l}\text { Tidak } \\
\text { Sesuai }\end{array}$ & $\begin{array}{l}\text { Sistem mendeteksi adanya perubahan pada semua } \\
\text { citra uji baik yang sebenarnya tidak ada perubahan } \\
\text { maupun yang sebenarnya ada perubahan }\end{array}$ \\
\hline
\end{tabular}

Keterangan:

A = Nilai threshold

$\mathrm{B}=$ Terdapat perubahan citra

$\mathrm{C}=$ Tidak terdapat perubahan citra

$\mathrm{D}=$ Keterangan

Nilai threshold yang telah ditentukan akan berpengaruh pada hasil deteksi perubahan citra. Semakin besar nilai threshold yang ditentukan maka nilai perbedaan antara citra referensi dengan citra uji yang diperoleh oleh sistem akan semakin tidak dianggap memiliki perbedaan. Sebaliknya, semakin kecil nilai threshold yang ditentukan maka nilai perbedaan antara citra referensi dengan citra uji yang diperoleh oleh sistem akan semakin dianggap memiliki perbedaan.

Dari hasil pengujian pada Tabel 2 dapat disimpulkan bahwa nilai threshold yang sesuai untuk semua data pengujian adalah berkisar antara 50000 - 100000 pixel. Maka untuk menentukan threshold untuk deteksi perubahan citra dapat dihitung:

$$
\text { Nilai threshold deteksi perubahan citra }=\frac{50000+100000}{2}=75000
$$

Maka dapat ditentukan nilai threshold untuk mendeteksi perubahan citra untuk masukan citra uji pada sistem deteksi perubahan citra ini adalah 75000 pixel. Nilai threshold hasil percobaan ini digunakan sebagai salah satu variabel untuk melakukan deteksi perubahan citra pada semua citra uji. Hasil percobaan yang dilakukan pada citra uji baik yang terdapat maupun yang tidak terdapat perubahan yang dijadikan dasar dari perhitungan precision, recall dan akurasi dari deteksi perubahan citra dimana dilakukan dengan nilai threshold yang telah ditentukan dari perhitungan sebelumnya ditunjukan pada Tabel 3.

Tabel 3 Akurasi hasil percobaan pada deteksi perubahan citra

\begin{tabular}{|c|l|c|l|l|l|}
\hline No. & Nama Citra & Perbedaan & Deteksi Sistem & $\begin{array}{c}\text { Deteksi } \\
\text { Seharusnya }\end{array}$ & Kesimpulan \\
\hline 1. & Out_1.jpg & 5835 & Tidak Ada & Tidak Ada & true negative \\
\hline 2. & Out_2.jpg & 11265 & Tidak Ada & Tidak Ada & true negative \\
\hline 3. & Out_3.jpg & 777956 & Ada & Tidak Ada & false positive \\
\hline 4. & In_1.jpg & 2741 & Tidak Ada & Tidak Ada & true negative \\
\hline 5. & In_2.jpg & 741814 & Ada & Tidak Ada & false positive \\
\hline
\end{tabular}
182




\begin{tabular}{|c|l|c|l|l|l|}
\hline 6. & Out_1_Objek.jpg & 1121789 & Ada & Ada & true positive \\
\hline 7. & Out_2_Objek.jpg & 921365 & Ada & Ada & true positive \\
\hline 8. & Out_3_Objek.jpg & 2325113 & Ada & Ada & true positive \\
\hline 9. & In_1_Objek.jpg & 597820 & Ada & Ada & true positive \\
\hline 10. & In_2_Objek.jpg & 1835985 & Ada & Ada & true positive \\
\hline
\end{tabular}

Berdasarkan pada persamaan (4) dan (5), maka precision dan recall dari hasil pengujian deteksi perubahan citra yang ditunjukan pada Tabel 3 tersebut diatas dapat dihitung:

$$
\begin{aligned}
& \text { precision (deteksi perubahan citra) }=\frac{5}{5+2} \times 100 \%=71.43 \% \\
& \text { recall }\left(\text { deteksi perubahan citra) }=\frac{5}{5+0} \times 100 \%=100 \%\right.
\end{aligned}
$$

Berdasarkan persamaan (6), maka akurasi deteksi perubahan citra dari hasil pengujian yang ditunjukan pada Tabel 3 tersebut diatas dapat dihitung:

$$
\begin{aligned}
\text { akurasi (deteksi perubahan citra }) & =\frac{5+3}{5+3+2+0} \times 100 \% \\
=\frac{8}{10} \times 100 \% & \\
& =80 \%
\end{aligned}
$$

Berdasarkan hasil pengujian, deteksi perubahan citra dengan menggunakan metode Illumination Invariant Change Detection pada kamera night vision memberikan hasil yang cukup baik dengan tingkat akurasi $80 \%$ dengan pemilihan nilai threshold deteksi perubahan citra yaitu 75000 pixel. Jika diperhatikan, kesalahan atau dalam hal ini hasil deteksi yang berupa false positive terjadi pada gambar yang diambil pada keadaan pencahayaan yang gelap yaitu pada nilai rata-rata Lux 0 dengan posisi lampu infrared yang menyala. Hasil dari simulasi pada keadaan tersebut ditunjukkan pada gambar 9. Jika diperhatikan, akuisisi citra pada keadaan pencahayaan yang gelap yaitu pada nilai rata-rata Lux 0 dengan posisi lampu infrared menyala dan fokus pada bagian tengah membuat komposisi pencahayaan menjadi berpusat pada area tengah saja. Hal ini mengakibatkan komposisi pencayahaan antara bagian tengah berbeda dengan keadaan pencahayaan pada bagian tepi pada area pengawasan dengan kamera night vision. Berdasarkan hal tersebut dapat disimpulkan bahwa metode Illumination Invariant Change Detection tidak dapat bekerja dengan baik untuk mendeteksi perubahan citra pada kamera night vision dengan hasil akurasi sistem sebesar $80 \%$. Akan tetapi, jika dibandingkan dengan hasil akurasi metode Illumination Invariant Change Detection dalam mendeteksi perubahan citra pada kamera pengawasan CCTV yaitu sebesar 92.86\%, nilai akurasi metode Illumination Invariant Change Detection dalam mendeteksi perubahan citra pada kamera night vision lebih rendah. Akan tetapi pada dasarnya hal ini tidak dapat dibandingkan karena baik objek, jumlah, dan variasi pengujian sistem dari masing-masing penelitian adalah berbeda. Selain itu, citra referensi yang digunakan dalam penelitian ini adalah citra referensi yang 
diambil dengan keadaan pencahayaan dengan nilai Lux 2080 yang digunakan sebagai pembanding dengan citra uji yang diambil dengan keadaan pencahayaan dengan nilai Lux 0 sampai 2, sedangkan pada penelitian sebelumnya tidak dijabarkan keadaan pencahayaan citra referensi.

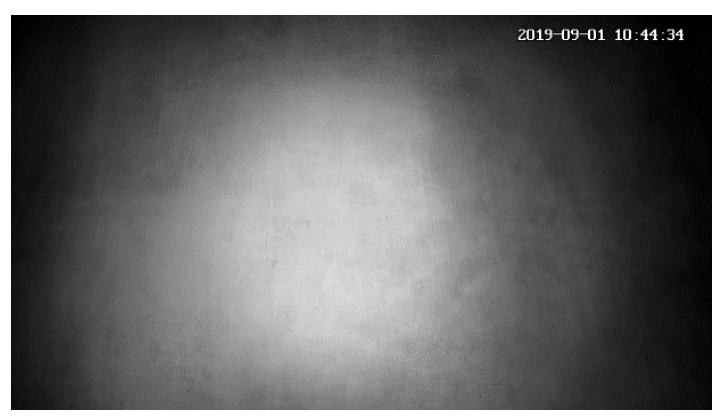

(a)

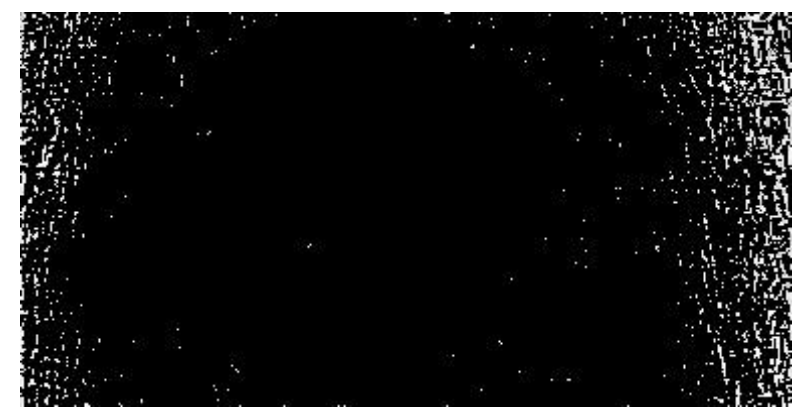

(b)

Gambar 9 (a) Citra pada keadaan infrared menyala (b) citra hasil simulasi akhir

\section{Kesimpulan}

Dari hasil perancangan, implementasi, pengujian dan analisa yang telah dilakukan, dapat disimpulkan bahwa metode Illumination Invariant Change Detection tidak dapat bekerja dengan baik untuk mendeteksi perubahan citra pada kamera night vision pada kondisi pencahayaan yang gelap yaitu pada nilai rata-rata Lux 0 dengan posisi lampu infrared yang menyala. Hasil akurasi dari penerapan metode Illumination Invariant Change Detection untuk mendeteksi perubahan citra pada kamera night vision adalah sebesar $80 \%$ dengan pemilihan nilai threshold deteksi perubahan citra yaitu 75000 pixel. Melihat kepada penelitian sebelumnya yaitu penerapan metode Illumination Invariant Change Detection dalam mendeteksi perubahan citra pada kamera CCTV dengan nilai akurasi sebesar 92.86\%, nilai akurasi metode Illumination Invariant Change Detection dalam mendeteksi perubahan citra pada kamera night vision ini lebih rendah. Akan tetapi pada dasarnya hal ini tidak dapat dibandingkan karena baik skema, objek, jumlah, dan variasi pengujian sistem dari masing-masing penelitian adalah berbeda.

\section{Daftar Pustaka}

[1] Ki, M., Cho, B., Jeon, T., Choi, Y., \& Byun, H. (2018, November). Face Identification for an in-vehicle Surveillance System Using Near Infrared Camera. In 2018 15th IEEE International Conference on Advanced Video and Signal Based Surveillance (AVSS) (pp. 1-6). IEEE.

[2] Kusuma, H., Wirawan, W., \& Suprijanto, A. (2015). Normalisasi Iluminasi Citra Wajah Dengan Menggunakan Histogram Remapping Pada Pengenalan Wajah Berbasis Fitur Gabor. JAVA Journal of Electrical and Electronics Engineering, 13(2).

[3] Megantara, R. A., \& Pramunendar, R. A. (2017). Pengembangan Background Subtraction Menggunakan FCM Untuk Deteksi Objek Bergerak Berdasarkan Pencahayaan Yang Bervariasi. Techno. Com, 16(4), 435-443.

[4] Putri, A. R. (2016). Pengolahan Citra dengan Menggunakan Web CAM pada Kendaraan Bergerak Di Jalan Raya. Jurnal Ilmiah Penelitian dan Pembelajaran 
Informatika, 1(01).

[5] Hadjkacem, B., Ayedi, W., Abid, M., \& Snoussi, H. (2017, October). A new method of video-surveillance data analytics for the security in camera networks. In 2017 International Conference on Internet of Things, Embedded Systems and Communications (IINTEC) (pp. 140-145). IEEE.

[6] Malathi, T., \& Bhuyan, M. K. (2013, April). Multiple camera-based codebooks for object detection under sudden illumination change. In 2013 International Conference on Communication and Signal Processing (pp. 310-314). IEEE.

[7] Augustin, M. B., Juliet, S., \& Palanikumar, S. (2011, March). Motion and feature based person tracking in surveillance videos. In 2011 International Conference on Emerging Trends in Electrical and Computer Technology (pp. 605-609). IEEE.

[8] Kim, I. S., Jeong, Y., Kim, S. H., Jang, J. S., \& Jung, S. K. (2019, July). Deep Learning based Effective Surveillance System for Low-Illumination Environments. In 2019 Eleventh International Conference on Ubiquitous and Future Networks (ICUFN) (pp. 141-143). IEEE.

[9] Choi, H., Dinh, Q., \& Jeon, M. (2018, January). Robust relationship learning to illumination in a camera network. In 2018 International Conference on Electronics, Information, and Communication (ICEIC) (pp. 1-4). IEEE.

[10] Wan, X., Liu, J., Li, S., Dawson, J., \& Yan, H. (2018). An illumination-invariant change detection method based on disparity saliency map for multitemporal optical remotely sensed images. IEEE Transactions on Geoscience and Remote Sensing, 57(3), 1311-1324.

[11] Wan, X., Liu, J., Qin, M., \& Li, S. Y. (2018). Illumination Invariant Change Detection (Iicd): From Earth To Mars. International Archives of the Photogrammetry, Remote Sensing \& Spatial Information Sciences, 42(3).

[12] Kim, W. H., Yi, K., \& Kyung, C. M. (2015). Energy-efficient illumination-invariant change detection in DCT coefficient domain for vehicular black box camera. Electronics Letters, 51(11), 822-824.

[13] Priadana, A., \& Harjoko, A. (2017). Deteksi Perubahan Citra Pada Video Menggunakan Illumination Invariant Change Detection. IJCCS (Indonesian Journal of Computing and Cybernetics Systems), 11(1), 89-98.

[14] Dawson-Howe, K. (2014). A practical introduction to computer vision with opencv. John Wiley \& Sons.

[15] R. C. Gonzalez and R. E. Woods.(2018). Digital Image Processing, 4th ed. New York: Pearson

[16] E. M. Martín and Á. P. del Pobil.(2012). Robust Motion Detection in Real-Life Scenarios, 1st ed. Springer-Verlag London. 
Adri Priadana 